\title{
FLYCATCHER FAMILY
}

JEAN BANCROFT, 306 - 200 Tuxedo Ave., Winnipeg, Manitoba. R3P OR3.

On many occasions during the past few years I have had an opportunity to observe the nests of several species of this interesting family. The season of 1980 proved to be no exception at Whytewold in the southeast corner of Lake Winnipeg.

To date I have been fortunate to observe six members of this family during a summer. For each species nest construction varies in size and materials used. However, one thing they do have in common is that they all get most of their food on the wing. They are quite acrobatic - diving up and down in the air and whirling around in order to catch insects such as midges, mosquitoes, fishflies, dragonflies, moths, etc.

A Great Crested Flycatcher has appeared in our yard for several years, but has always chosen to nest somewhere else in the immediate area. This past spring my hopes were high when I noticed two adults investigating a large old nesting box in our yard. But, after flying in and out of the opening, they chose another nesting site. However, later on both adults and their fledglings flitted about the wooded area surrounding our cottage for several days.

An Eastern Wood Pewee chose to build its nest on the lowest dead branch of an old oak just outside our back fence. I was able to view the nesting from our door. In my experience with several pewee nests, this bird always has chosen a horizontal lichen-covered limb of an old oak whereon to build. It is amazing how the female gathers, in her tiny beak, fragments of silken threads left hanging by caterpillars and/or spiders. Little pieces of the fine grasses are woven into the structure as well, and then she sheathes the outside with lichens. It is a dainty nest, not quite 7.5 $\mathrm{cm}$ in diameter and blending in with its surroundings. To date I have found no variation in materials used. Construction of the nest is done with such infinite patience and artistry that it takes almost a whole week to accomplish.

The Eastern Wood Pewee can be recognized from the Empidonax Flycatchers by the fact that it is a bit larger, "lacks an eye-ring, and its longer wing extends halfway down the tail." "Its plaintive call of pee-a-wee (pause) peea clearly identifies it.

On 19 April 1980, I noticed a male and female Eastern Phoebe following each other from tree to tree about a block away from where a phoebe had built a nest in 1979. This bird is slightly larger than the pewee and is known for its tail wagging. I was disappointed that did not find the nesting site in 1980. Due to the very dry spring, many birds which use wet mud for nest construction found it very difficult indeed. In 1979 I discovered the nest underneath the fron canopy of a cottage, quite close to the front door, and on a $4 \times 4$ beam. The nest had been built some time before the owners of the cottage had arrived. They did not wish to disturb the birds so they did not use their front door during the whole nesting period. The nest was constructed mainly of mud so that it was readily visible on the white-painted beam.

On all occasions, when I stood out side the fence to make my observations the adults were very wary of $m$ y presence; the female kept perfectly stil while huddled down in the nest, and the male concerned himself with foragin: for insects in and around the yard, fre quently giving his sharp chip call. 
When the owners of the cottage had ome construction work done, I thought hat the birds might forsake the nest but hey did not. On a subsequent occasion was permitted to climb a ladder to inestigate, and was delighted to see four airly large nestlings. Although I was not resent when the fledglings left the nest, ter I did see and hear the adults and ome of the young not far from the esting site.

This past summer I had an interesting xperience with a Least Flycatcher. I ave generally been able to observe two three nests of the Least per year and ave always listened for the chebec call. Godfrey states, it is "very similar to aill's Flycatcher but its call identifies it stantly in spring and summer." This ast spring a male Least established his territory in our yard. He just never ceased to give his emphatic call of chebec, chebec, chebec for many days. The chebec was repeated 25 times to the minute. I understand that this call has been known to have been repeated 50 times per minute. This particular male decided to make himself king of all he surveyed because he frequently flew to the very top of a dead poplar, approximately $12 \mathrm{~m}$ high, and continued off and on with his repetitive call. During this period I kept looking with my binoculars, wondering where the nest was. Suddenly, I found it about $7.5 \mathrm{~m}$ from the ground. It was saddled close to the end of a horizontal branch of an old oak and, although the limb was partly bare, the nest was protected by two leafy offshoots. The temale sat so low in the nest that only her head was visible, permitting me to see the eye-ring 


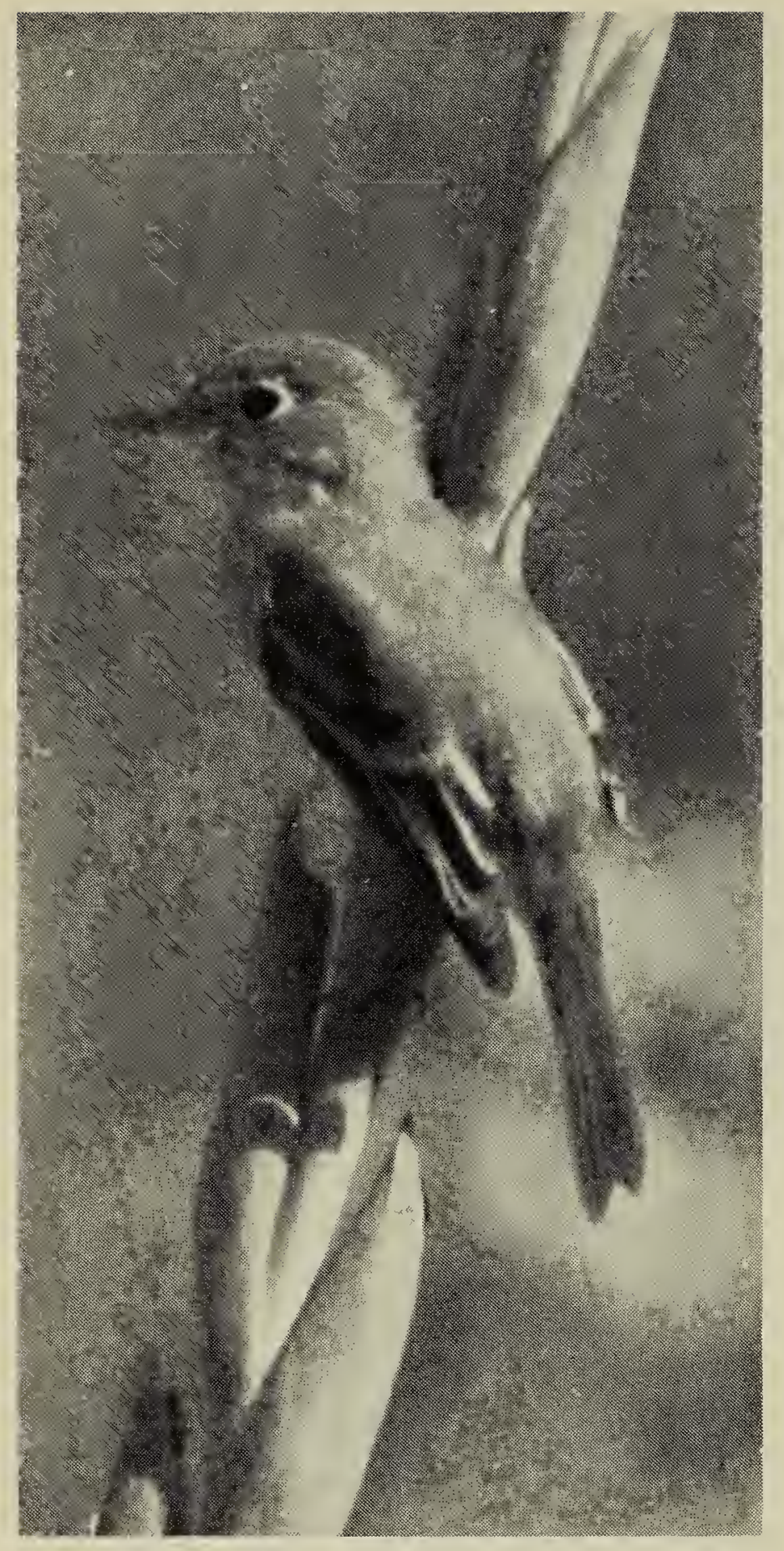

Empidonax Flycatcher

Sheina Wait

The bird had used several pieces of white string and strips of yellow kleenex (which I had put out for nest building purposes) and had woven some plant fibres into these man-made materials. On numerous occasions I heard the warning call - whit. This call increased noticeably when the four young had been fledged, as they and the adults remained for several days in the wooded area surrounding our cottage.

Although I have seen the Western Kingbird every season in the vicinity of the Lake Winnipeg beaches, it has been several years since I have been able to locate a nest here.

In 1980 the Eastern Kingbird was present in large numbers, and I should like to note a particularly interesting nest of this bird.

One day a friend came to me and asked if I would come to his yard and identify a bird he had observed nesting in a tall oak tree close to his sundeck. I hurried over with my binoculars and I was surprised to see an Eastern Kingbird sitting on a nest constructed mainly of wool-nylon yarn (4-ply medium blue, 3-ply pale blue and 3-ply white). These were materials I had originally put out in our yard as an experiment. It appeared that the nest had very few plant fibres, just enough to bind the $20-\mathrm{cm}$ lengths of yarn together. At the base was a tangled clump of white yarn and around the top there was some more. There was a patch of the medium blue on either side of the nest, and the pale blue was woven into the nesting material and also wound around the tree limb which was about $9 \mathrm{~m}$ from the ground. I was particularly surprised to see the medium blue yarn because not a single bird of any kind had picked up this colour in 1979 (which was the first year I had put it in the yard).

I wondered how this nest would fare, in view of the various colours not blending in with the natural surroundings. But I was able to keep a record of the nesting and, to my delight, one morning I saw the four fledglings huddled very close to the nest, their snowy white breasts blending in perfectly with the white yarn around the top of the nest. What a beautiful picture they presented!

I feel fortunate that I have been able to observe the nesting habits of so many members of the Tyrannidae family at Whytewold.

'GODFREY, W. E. 1966. The birds o Canada. Nat. Mus. Canada Bull. 203. Ottawa. 